\title{
INTERNATIONAL RELATIONS DATA FILES FROM ICPSR
}

\author{
JUDITH S. ROWE \\ Associate Director for Academic Data and Program Service, Princeton University Computer Center, \\ 87 Prospect Avenue, Princeton, N.J. 08544, U.S.A.
}

\section{SANTA TRAUGOTT}

Assistant Archival Director, Inter-University Consortium for Political and Social Research, The University of Michigan, P.O. Box 1248, Ann Arbor, MI 48106, USA

Progress in international studies, as in other areas of the social sciences, has resulted in a need for larger and more complex data collections. The Inter-University Consortium for Political and Social Research has evolved in the past two decades to meet such needs. As a result of the willingness of scholars to use Consortium archiving, training, and disseminating facilities, the utility of costly data collections has been multiplied many times over. A wide range of data collections now exists both to serve the purposes of secondary analysis, replication and verification, and to be employed as building blocks in the operationalizing of new research designs. The extended resources of the Consortium's rich and varied data holdings make possible serendipitous use by international studies specialists of data collections originally produced for use in other subfields of the social sciences. Continuing recognition by international relations specialists of the scholarly obligation to share data with others has ensured continuing development of these rich resources.

The Consortium was formed in 1962 as a partnership for research and instruction among 21 colleges and universities. At that time, its primary focus was the series of election studies conducted since 1952 at the Institute for Social Research. In the last 20 years, the Consortium has grown to a membership of over 260 academic institutions and has expanded its holdings into a wide variety of scholarly arenas.

One of the first areas in which the Consortium hegan to expand its holdings was international relations. This article reviews these holdings, which are now numerous and varied, and invites the assistance of specialists in the IR field in identifying datasets helpful to research in this area which are not now held by the Consortium.

While a relatively small proportion of Consortium holdings in IR were directly produced by U.S. or international governmental agencies, most of the IR data collections were at least partially funded by various agencies of the U.S. government, and grants from the federal government have been of material assistance to the Consortium in archiving many of the IR data collections in their present form. Since the number of IR holdings is quite large, it is possible to list here only some of the more widely utilized collections, particularly those produced by government agencies and those with most current data.

Uscrs should be aware, too, that ICPSR has many collections which are not usually labeled as "IR" but which may, nonetheless, be relevant to research interests in the IR field. For example, the Consortium has an extensive collection of single-nation and comparative 
survey data. These surveys range from studies of political participation across nations to examinations of worker attitudes and aspirations within nations. Perhaps the series most familiar to IR researchers is the archive's collection of election studies which includes surveys from fourteen nations and spans nearly twenty years. The Consortium also has a large body of quantitative historical data which researchers in International Relations might find useful, including census data, election returns, proceedings of legislative organizations, and a wide variety of social indicators. For a complete list of Consortium holdings, users should consult the ICPSR's Guide to Resources and Services (available upon request by writing to ICPSR, P.O. Box 1248, Ann Arbor, Michigan 48106, or calling 313-764-2570).

Access to Consortium holdings listed below and in the Guide is open to all, although the cost of obtaining a data collection is different for different groups of users. The Consortium is a membership organization, in which membership is limited to academic institutions, paying an annual membership fee. Data resources of the ICPSR are provided without charge to persons at member institutions. For nonmembers, data resources are provided at a cost which varies according to the data requested and the requestor's circumstances. The potential data user should contact: Member Services, ICPSR, P.O. Box 1248, Ann Arbor Michigan, 48106, or call 313-763-5010.

If there is a common denominator in the field of international relations, it is in the concept of outcomes of interaction or conflict between nations, and perhaps more specifically, in the explanation of why some outcomes are warlike, others not. Certainly many of the most widely used Consortium holdings are in the domain of "events" data, which record the public, peaceful or otherwise, events between (and sometimes within) nations. These are typically not government-produced files, or even coded by private investigators from government documents. Usually, these are publicly funded collections, or have been archived using government funds. Data collections in this category are:

- CACI, Inc. - Federal. U.S. and U.S.S.R. Crises, 1946-1976. This study contains three files of information on international crises; two deal with 386 crises that were of concern to the U.S. and one with crises of concern to the Soviet Union.

- Hermann, Charles et al., Comparative Research on the Events of Nations (CREON) Project: Foreign Policy Events, 1959-1968. Contains 11,961 foreign-policy events of 36 countries. There are 167 variables, including actor, target, date, indirect objects, types of events, resources involved and internal decision units. The data are coded for randomly selected quarter years of the 10-year period. The source used for the coding of events is the uncollapsed version of Deadline Data on World Affairs.

- McClelland, Charles. World Event/Interaction Survey (WEIS) Project, 1966-1978. Each of the 81,240 cases in the data is a report of an international event, i.e., words or deeds communicated between nations. Coded for each event is the actor, target, date, action category, event code, and arena. The primary source of the data is the New York Times. Additional sources are used to check reliability and validity.

- McGowan, Patrick. Southern African Subsystem Events Data, 1973-1976. Data for 19 variables on some 13,000 events related to affairs in Southern Africa. Variables include action, issue area coding, date, and other event characteristics. Data were primarily coded from Africa Research Bulletin (Political Series), Africa Research Bulletin (Economic Series), and Chronologie Politique Africaine.

- Mickolus, Edward F. International Terrorism: Attributes of Terrorist Events 1968-1972. The data consist of information for 5,539 incidents in international terrorism. 148 variables measure each incident in terms of the characteristics of the international terrorist groups, the impact of terrorist activities on the international system, and the environments 
in which terrorist activities occur. (The Consortium will release a new version of this file, updated through 1977, in Spring, 1982.)

A set of variables that have often been examined in relationship to outcomes of conflict is the arms trade between nations and comparative expenditures on arms and defense. In this area, the Consortium disseminates a number of files, and here the data is typically government produced or coded from government sources.

- Leiss, Amelia. Arms Transfers to Developing Countries, 1945-1968. Data on arms transfers to 52 less-developed countries. The transfer is the unit of analysis. A second file of data contains detailed coded information about each weapons system.

- Mullins, Alden F., Jr. Military Personnel and Weapons Stocks in Newly Independent Slates, 1957-1976. Contains data for 37 newly independent states for the years in this period in which they were independent. Variables include country, year, total military personnel and stocks present of 208 weapons.

- Gillispie, John and Dina Zinnes. Military Defense Expenditure Data, 1948-1970. Data for 123 nations. Data are provided either in U.S. dollars or national currency with an exchange rate provided.

- Sivard, Ruth Leger. World Military and Social Expenditures, Annual Files for 19741980. These datasets contain information on national resources and social and military expenditures, where data values are given as aggregate, aggregate ranked, per capita, and per capita ranked. Data are given for 140 countries. Data are coded from numerous statistical sources. Some of the primary sources are the UN, World Bank, IMF, OECD, WHO, USAID, International Institute for Strategic Studies and NATO.

- U.S. Arms Control and Disarmament Agency. World Military Expenditures and Arms Transfers. Data exists from 1963-77. The Consortium expects to make available 1978 and 1979 files some time this winter. Elements of this collection are financial data, in current and constant dollars, of arms exports and arms imports; most of the years also contain data on GNP and population.

Collections of data relating to international economics, social expenditures, and demography are likely to derive from government sources of data including the World Bank, the United Nations, and the International Monetary Fund as well as the U.S. Government. Some of the major files in this area are:

- International Monetary Fund. Direction of Trade. Data include the source of imports and destination of exports by country for about 160 countries. All series are expressed in U.S. dollars. These data are given annually. There are 40,000 records, each record having 35 variables. Data from these series are published monthly in International Monetary Fund, Direction of Trade.

- International Monetary Fund. International Financial Statistics, 1948-1978. This is an ICPSR created subset of the International Financial Statistics data which consists of annual data for these years, and is currenty being updated through 1981. There are 16,250 records with 31 variables which summarize every country's balance of payments as well as principal components and cause and effect elements. Data from these series are also published monthly in International Monetary Fund, International Financial Statistics.

- National Bureau of Economic Research. Macroeconomic Time Series for the U.S., U.K., Germany and France. For these countries, there are time series measuring production, construction, prices, income, employment, inventories, sales, interest rates, money supply, and a variety of other factors. The NBER collection, containing an estimated 1.6 million entries, is currently available as 24 datasets. The economic variables are usually 
observations on the entire nation or on large subsets of the nation. Chronologically, most data fall within the first half of the twentieth century, although many series extend into the nineteenth century and a few reach into the eighteenth. Most of the data are monthly. Data were entered by the ICPSR staff from documents provided by NBER.

- United Nations. Commodity Production Statistics, 1967-1979. The units in this file are country by year by commodity. The variables are measures of quantity. This file contains the input data to the Yearbook of Industrial Statistics Vol. 2. (This file is being readied for dissemination in early spring, 1982.)

- United Nations. Cross-National Population by Age and Sex, 1966-1974. This dataset includes total population by country or area for 220 countries for males and females divided into 18 age groups.

- United Nations. Cross-National Statistics on the Causes of Death, 1966-1974. This dataset contains, for some 220 countries, statistics on about 50 various causes of deaths for the years given for males, females, and total populations. Data were obtained from three major sources: UN Demographic Yearbook, UN Demographic Yearbook Questionnaire, and various national publications.

- United Nations. General Industrial Statistics, 1967-1979. The units are country by year by industry. The variables are value and quantities of items produced. This file contains the input data for the UN Yearbook of Industrial Statistics, Vol. 1. (This file is being readied for dissemination in early spring, 1982.)

- United Nations. Historical Supplement to the Demographic Yearbook, 1948-1978. These files were prepared as a supplement to the 1980 Yearbook, and contain time series on population size, age, sex, urban-rural residence, natality, mortality, and nuptiality, as well as selected derived measures concerning these components of population change for a 30 -year time period. The unit of analysis is ethnic group within country, by year. (This file will be disseminated in early spring, 1982.)

- United Nations. Index of Industrial Production. For each country, year industry and month covered, the record contains the quantity of items produced, units measured, and value.

- United Nations. World Energy Yearbook, 1980. Contains 115,000 logical records. In this file a record refers to an individual reporting country and its quantity of production, trade, etc. of a commodity. This file contains the data published in the United Nations Yearbook of World Energy Statistics, 1980. New York, 1980. (This file is being readied for dissemination in early spring, 1982.)

- U.S. Agency for International Development. Economic and Social Indicators for Eighteen Latin American Nations, 1960-1971. Seventy-eight variables where the unit of observatin is the nation-year. Variables include government expenditures in various areas, food production, education, membership in co-operatives, transportation and health.

- U.S. Department of Commerce, Bureau of the Census. World Population, 1973. This dataset has 10 variables, including births and deaths per 1,000 population, infant deaths, population increase, life expectancy, population under 15 , years to double population, median age of mother, median birth order, and urban population for some 160 political entities in the world. (1979 edition is on order.)

- U.S. Department of Commerce, International Statistical Program. World Population. 1950-1975. The data consist of 27 demographic variables for 201 nations and other international political entities. Variables include population for each year 1950-1975, plus 1975 birth, death, and growth rate figures. Sce U.S. Bureau of the Census, International Statistical Programs Center, World Population: 1975-Recent Demographic Estimates for the Countries and Regions of the World. 
- World Bank. Cross-National Economic Time Series, 1950-1975. This collection includes two data files. The first contains time-series data for national accounts and prices for each year, (47 variables for 125 countries) and Balance of Payments and Central Government Finance for 1966-1975 for 67 developing countries. The second file, the Social Indicators dataset, consists of 43 variables for both developing and industrialized countries. The data cover six areas: health and nutrition, education, housing and consumption, demographic characteristics, population, and employment and income.

Two important, but very different series, may be classified together as relevant to the study of international integration. Both of the series have been funded for some substantial part of their existence by the U.S. government.

- Rabier, Jacques-Rene and Ronald Inglehart. European Community Studies and Eurobarometers, 1971-1980. These studies include survey samples from nine (later ten and eleven) European countries. While the focus of each of the semiannual surveys has varied, and while the studies are primarily "comparative," a significant part of each survey has always been devoted to attitudes toward European integration and unification. Reports are published annually by the Commission of the European Communities; for example, Euro-Barometre 8 Brussels, January 1978.

- ICPSR. United Nations Roll Call Data, 1946-1974. General Assembly roll calls for the First to the Twenty-ninth Plenary Sessions, the First to the Fifth Special Sessions, and for the seven committees. The Consortium is currently processing roll calls for the years 1975, 1976, and 1977. We expect to release these in summer 1982. Roll-call votes for at least the General Assembly for the years 1978-1981 will probably be released by the end of 1982 . Roll calls are coded from United Nations, Proceedings of the United Nations, 1946. 